\title{
Derleme (Review) \\ Koyunlarda Mizacın Bazı Verim Özellikleri ile İlişkisi ve Seleksiyonda Kullanım Olanakları
}

\author{
Cihan ÇAKMAKÇI*, Serhat KARACA \\ ${ }^{1}$ Yüzüncü Y1l Üniversitesi, Ziraat Fakültesi, Zootekni Bölümü, Van, Türkiye \\ *e-posta: cakmakcicihan@gmail.com
}

\begin{abstract}
Özet: Son yıllarda gerek hayvan refahının iyileştirilmesi gerekse üretimin arttırılmasına yönelik çabaların hız kazanmış olması bu alana yönelik yeni yaklaşımlara ihtiyaç duyulduğunu göstermektedir. Hayvan refahı, dünyanın birçcok ülkesinde hızla artan bir endișe konusu haline gelmiş ve bu endişeler yetiştiricilerinin kullandıkları bakım-besleme ve tedavi yöntemlerinde bazı değişikliklere gidilmesine yol açmıştır. Bu bağlamda, mizaca yönelik seleksiyon ile yönetimsel uygulamalara bağlı çeşitli çevresel stres faktörlerinden daha az etkilenen bireylerin damızlığa seçimi, hayvancılık sektöründe istenen yapıda sürüler elde etmek, hayvan refahını korumak ve verimliliği iyileştirmeye yönelik alternatif bir yöntem olarak görülmektedir. Bu derlemede; strese yanıt mekanizması koyunlarda mizaç ile ilişkili olarak incelenmiş ve mizacı değerlendirmede kullanılan mevcut yöntemler özetlenmeye çalışılmıştır. Ayrıca çeşitli davranış özellikleri ile üretim arasındaki ilişkiler irdelenerek bir seleksiyon özelliği olarak mizacın kullanım olanakları değerlendirilmiştir.
\end{abstract}

Anahtar kelimeler: Hayvan refahı, korku testleri, koyun, mizaç, seleksiyon, stres

\section{Relationship between Temperament and Some Production Traits and Possibility of Using Temperament as a Selection Criteria in Sheep}

\begin{abstract}
Increased effort to enhance both animal production and welfare, indicates that new approaches are needed in this subject. Animal welfare is a subject of increasing concern in many countries around the world, and this concern causes animal users to change the ways of keeping and of treating their animals. In this context, selection of individuals which are less affected by various environmental stress factors related to management practices, depending on their temperament can be seen as an alternative method to obtain desired flock in animal production, to protect animal welfare and to improve productivity. In this review, stress response mechanism has been investigated in relation to temperament in sheep, and the existing methods used to evaluate temperament have been summarized. In addition, the relations between various behavioral characteristics and production were examined and the usage possibilities of temperament as a selection parameter were considered.
\end{abstract}

Keywords: Animal welfare, fear tests, sheep, temperament, selection, stress

\section{Giriş}

Hayvan refahı, dünyanın birçok ülkesinde hızla artan bir sorun haline gelmiş ve bu endişeler yetiştiricilerinin uyguladıkları bakım-besleme ve tedavi yöntemlerinde bazı değişikliklere gidilmesine yol açmıştır (Broom 2008). Refah, hayvanın çevresindeki zorluklarla başa çıkma çabası olarak ifade edilmektedir (Broom 2003). Hayvan refahıyla ilgili olarak yapılan çalışmalar iki konuda yoğunlaşmaktadır. Bunlardan ilki; hayvanlarda refahın nasıl belirleneceği, diğeri ise refahın belirlenmesinde nasıl bir yöntem/yöntemler uygulanacağıdır (Moberg ve Mench 2000). Son birkaç yılda hayvan refahının değerlendirmesinde yeni indekslerin geliştirilmesinde oldukça ilerleme kaydedilmesine rağmen, birden fazla davranışın sergilenmesi, biyokimyasal ve fizyolojik ölçümlerin mevcut olması bütün bunların nasıl entegre edileceği sorununu da beraberinde getirmektedir (Dawkins 2004).

Çiftlik hayvanlarında stresin azaltılmasına yönelik çalışmalar, genellikle yönetsel uygulamalarda değişikliğe gidilmesi şeklinde olmuştur. Ancak diğer bir seçenek ise hayvanların yönetim uygulamaları 
esnasında oluşan stres ile başa çıkma kabiliyetlerini geliştirmektir. Bu genetik olarak iyi mizaca sahip hayvanların seçimine yönelik uygulamalar ile sağlanabilir (Dodd ve ark. 2012).

$\mathrm{Bu}$ derlemede strese yanıt mekanizması koyunlarda mizaç ile ilişkili olarak incelenmiş ve mizacı değerlendirmede kullanılan mevcut yöntemler özetlenmeye çalışılmıştır. Ayrıca çeşitli davranış ve verim özellikleri arasındaki ilişkiler irdelenerek bir seleksiyon ölçütü/parametresi olarak mizacın kullanım olanakları değerlendirilmiştir.

\section{Stres mekanizmasl}

Stres

Günlük hayatta her ne kadar yaygın olarak kullanılan bir terim olsa da stresi tanımlamak oldukça zordur (Lupien ve ark. 2007; Ralph ve Tilbrook 2016). Broom (2003), stresi birey üzerindeki kontrol sistemini baskılayan ve seçilim değerini düşüren çevrenin etkisi olarak tanımlamakta ve bireyin bir sorunla başa çıkmadaki başarısızlığı durumunda stres yaşadığını belirtmektedir. Ralph ve Tilbrook (2016)'da stresi homeostasise yönelik gerçek ya da algılanan bir tehdit varlığında bir dizi bütünleşik ve davranışsal süreci barındıran kompleks fizyolojik bir durum olarak tanımlamaktadırlar. Tehdidin stres olduğu ve strese verilen yanıtların hayvan sağlığını riske atacak kadar önemli biyolojik değişikliklere neden olduğunda hayvan refahı sorun haline gelebilmektedir (Moberg ve Mench 2000).

Stres, şiddetli olduğunda homeostatik süreçler anormal baskı altına girmekte, davranışlar düzensizleşmekte ve patolojik etkiler meydana gelebilmektedir (Gregory 2008; Earley ve ark. 2010). Gregory (2008), stresi genellikle ya stresin meydana geldiği koşullara ya da stres tepkisine neden olan etmenlere göre sınıflandırılmakta olduğunu bildirmiş̧ir.

\section{Stres Etmeni/Uyarıclar}

Stres etmeni, organizmada bir dizi fizyolojik, psikolojik ve davranışsal değiş̧iklikler oluşturan içerden ya da dışarıdan gelen uyaranlar olarak tanımlanabilir. Earley ve ark. (2010), stres etmenleri fiziksel/çevresel olanlar ile psikolojik/algısal şeklinde iki grupta sınıflandırmaktadırlar. Fiziksel stres unsurlarını aşırı sıcaklık, yem ve/veya su sınırlaması, ağrı ve hastalık olarak sıralarken; psikolojik stres ise genellikle günlük rutin uygulamalarda yapılan değişiklikler, korku, kısıtlama ve/veya izolasyon, farklı/sıra dışı görüntü ve sesler ve insanlar da dahil olmak üzere algılanan yırtıcı varlığı gibi faktörleri içermektedir. Hayvanın stres etmenlerine olan tepkisi önceki uygulama ve deneyimler, stres etmenlerine maruz kalma süresi, bu etmenin akut ya da kronik olup olmamasından etkilenebilmektedir.

Bir stres etmeni ile başa çıkmak için kullanılan bütün biyolojik savunma sistemleri bireyin biyolojik yapısını değiştirebilmektedir. Stres esnasında meydana gelen değişiklikler, stres etmeninden önce meydana gelen faaliyetlerde kullanılan kaynakların kullanımında değişikliklere neden olmaktadır. Stres esnasındaki bu değişikliğe "stresin biyolojik maliyeti" denir. Stresin süre ve düzeyi yüksek olduğunda, bu maliyet oldukça önemli olmaktadır ve stresle başa çıkma çabası vücuda önemli bir yük haline gelmektedir (Moberg ve Mench 2000).

\section{Stresin fizyolojik yanıtları}

Stresi tanımlamada kullanılan teorilerden hiç birisi tek başına evrensel kabul görmemektedir. Ancak, Selye (1952)'nin üç aşamalı genel adaptasyon sendromu gıda üretimi amacıyla yetiştirilen hayvanlarda stres araştırmaları temelinde birinci teori olmaya devam etmektedir (Etim ve ark. 2013).

1-Uyarım aşaması: $\mathrm{Bu}$ aşama genel olarak, hem merkezi sinir sistemi hem de kan dolaşımı ile çevresel düzenlemelere karşı oluşan ani tepkiler için hayvanları hazırlayan kısa süreli (akut) davranışsal ve hormonal yanıtları düzenlemektedir (Earley ve ark. 2010). Bu aşama; sempatoadrenal medüller sisteminin uyarılması ile adrenalin ve noradrenalin gibi hormonların salgılanmasını içerir. Adrenalin bronşların ve göz bebeklerinin genişlemesine sebep olur; Solunum ve nabız sayısı gibi bazı fizyolojik değişimlerin yanı sıra terleme gibi davranışsal belirtilerle bazı yanıtlar gösterir (Earley ve ark. 2010). 


\section{C. ÇAKMAKÇI, S. KARACA}

2-Adaptasyon/Direnç aşamast: Uzun süreli (kronik) yanıtlar ise beyinde strese karşı önemli nöroendokrin, bağışıklık ve metabolik yanıtları içerir. Stres devam ederse, sinyal hipotalamus medyan eminens hücreleri tarafından kortikortropin serbest bırakma faktörü (CRF) salgılanmasını uyararak portal venöz sisteminden hipofiz ön lobuna taşınmasını sağlar. Buradan adrenal korteks üzerine doğrudan etki eden ve kortikoidler olarak bilinen çeşitli hormon salınımını düzenleyen, damar sistemi boyunca taşınan adrenokortikotropik hormon (ACTH) salınımını sağlar (Rice 2000; Earley ve ark. 2010).

3-Tükenme aşaması: Eğer organizmanın stres öncesi haline dönmesi mümkün değil ya da ilk aşamada oluşan kötü durum fazlaysa, canlıda tükenmişlik sendromu şekillenir. Bu aşamada, hormon salgıları artar; kortizolün dolaşım sistemindeki yüksek salgı düzeyi ile birlikte bağışıklık, sindirim ve diğer sistemlerde olumsuz etkileri belirmeye başlar. Enerji kaynaklarının tükenmesiyle dokularda kalıcı hasar ve aşınma veya ölüm gerçekleşir (Rice 2000).

\section{Stresin davranışsal yanıtları}

Evcil koyunların yaşadığı göreceli korku, davranışsal ve fizyolojik stres ölçütlerindeki değişiklikleri belirlemek suretiyle bir olayla ilgili bir sonuca varılabilir ya da yorum yapılabilir. Aynı zamanda koyun yetiştiriciliği uygulamaları esnasında ortaya çıkan bu tür stres düzeyleri karşılaştırılabilmektedir (Beausoleil 2006). Herhangi bir stres etmenine maruz kalan hayvanlar türe özgü davranış kalıpları kullanarak bu stres etmenlerine yanıt verirler ve bu yanıtlar açısından bireyler arasında farklılıklar mevcuttur (Pehlivan ve Dellal 2014). İlk deneyimler, genotip, yaş, sosyal ilişkiler ve insan-hayvan etkileşimi gibi faktörler strese yanıtın yapısını değiştirebilmektedir (Moberg ve Mench 2000). Ayrıca, günlük ritim, fizyolojik durum, cinsiyet ve popülasyon yoğunluğu gibi unsurlarda strese karşı gösterilen bireysel yanitları etkileyebilmektedir (Pehlivan ve Dellal 2014).

Hayvan davranışlarındaki bireysel farklılıklar genellikle mizaç ile ilişkilendirilmektedir. Mizaç, her biri bağımsız olarak davranışsal tepkiler üzerine etkili olabilen birden fazla boyut içeren (Beausoleil 2006; Beausoleil ve ark. 2012) fenotipik bir özelliktir (Blache ve Bickell 2010). Mizaç kavramı, davranış1 anlamak için kullanılan varsayımsal bir araçtır. Bu kavram üç düzeyde tanımlanabilir. Bunlardan en yaygın olanı yüzeysel davranış yani bireyin strese olan davranışsal tepkisidir. Daha derinlemesine irdelendiğinde, mizaç strese nöro-endokrin sistemin yanıt biçimi olarak görülmektedir. Üçüncü aşamada ise mizaç stres uyaranına karşı bir hayvanın belirli bir şekilde yanıt vermeye yönelik kalıtsal bir temeli olan doğal potansiyeli olarak görülmektedir. Kalıtsal mizaç, genetik ve erken yaşam deneyimleri gibi kalıcı çevresel etkiler tarafından belirlenir ve zaman içinde değişmez, fakat ifade şekli hayvanın geçici çevresi ve fizyolojik durumundan etkilenir (Dodd ve ark. 2012).

Uygulamalı etoloji literatüründe "mizaç" korku yaratan muhtemel durumlarda veya olaylara karş1 hayvanların gösterdiği tepkileri tanımlamakta sıklıkla kullanılmaktadır (Beausoleil 2006; Beausoleil ve ark. 2012). Mizaç, insanlar için “davranış, his ve düşünme yollarının doğal kontrolü” olarak tanımlanmıştır. Hayvanlar için ise, mizaca yönelik algılar temelinde benzer kriterlere başvurularak birçok tanımlama girişiminde bulunulmuştur (Blache ve Bickell 2010). Blache ve Ferguson (2005) mizac1, ürkeklik duygusu, bir hayvanın insan ile teması ve/veya yeni ortama veya tehdit edici çevreye tepki sonucu oluşan reaksiyon olarak tanımlamaktadırlar.

Bir hayvanda mizaç ifadesi o hayvanın davranışsal tepkisidir (Dodd ve ark. 2012). Bireysel olarak koyunların kendilerine ait mizaç veya duygusal tepkileri vardır. Bazı koyunlar izolasyon, yeni ortam ve insanlar ile yakın temasta daha sakinken bazıları benzer durumlar ile başa çıkmada zorluklar yaşamakta ve daha gergin olabilmektedirler (Blache ve Ferguson 2005).

\section{Korku}

Potansiyel tehdit durumlarına tepki göstermede bireyin genel duyarlılığı korku olarak tanımlanmakta ve çeşitli hayvan türlerinde mizaçla ilişkili bir özelliği olarak varsayılmaktadır. Korku, ölçümü genellikle korkunun değişen koşullar karşısında tutarlı ve zamanla değişmediği varsayımına dayandırılmaktadır (Miller ve ark. 2006). Korku, genellikle gerçek bir tehlike algısına karşı gösterilen tepkiler olarak tanımlanmaktadır (Forkman ve ark. 2007). Bu tepkiler hayvanı tehlike ile başa çıkması için hazırlayan fizyolojik ve davranışsal reaksiyonlar ile ifade edilir. Doğal yırtıcılar insan denetimi altında tutulan 
hayvanlar için büyük ölçüde yok olmasına rağmen, davranışsal tepkilerle birlikte, mekanizma ve hislerin varlığ devam etmektedir (Forkman ve ark. 2007).

Korku, türlerin evrimsel tarihine ilişkin olarak (atadan gelen korkular / doğuştan gelen korkular) yükseklik ve karanlık gibi belirli bir uyaran tarafından ortaya çıkarılabilir. Buna ek olarak, önceki deneyimlerle bağlantılı bir olay (şartlı korku) da korku yaratabilmektedir (Forkman ve ark. 2007). Gregory (2008), hayvanlarda korkunun yaygın olarak tanınan dört tipi vardır. Bunlar sırasıyla; (1) doğuştan gelen korku, örneğin izolasyon, karanlık korkusu, (2) yenilik, örneğin garip nesneler, ani hareketler, (3) deneyimle ögrrenilen korkular, örneğin beklenilen ağrllar ve (4) diğer hayvanlarda korku belirtilerinin yarattı̆̆ korkular olarak bildirmektedir.

İnsana karşı azaltılmış korku, genellikle evcilleştirmenin önemli bir bileşeni olarak kabul ediliyor olsa da (Forkman ve ark. 2007), insan ve evcil koyunlar arasındaki ilişkinin niteliği hakkında kesin bir bulgu yoktur (Beausoleil 2006). Ancak, evcil koyunlar halen insan varlığında kaçınma, stres ve korkuya işaret eden davranışsal ya da fizyolojik tepkiler göstermektedirler (Beausoleil 2006; Forkman ve ark. 2007).

Çiftlik hayvanlarında korku, işletme rutininde ve belirli dönemlerde yapılan kırkım, kastrasyon, kuyruk kesimi, boynuz köreltme, aşılama ve taşıma gibi çeşitli sürü yönetimi/pratik yetiştirme işleri esnasında oluşan yaygın bir stres faktörüdür. Koyunlarda korku stresi tetikliyor olsa dahi, bazı hayvancıllk uygulamaları gereklilik olarak görülmektedir (Beausoleil ve ark. 2012). Ancak, aşırı korku temel davranışları değiştirerek hayvan idaresini zorlaştırmakta (Gregory ve Grandin 1998; Forkman ve ark. 2007) ve verimliliği, ürün kalitesini ve hayvan refahını olumsuz etkileyebilmektedir. Korku seviyesi, son derece ürkek hayvanların yaşam koşullarından dolayı daha yoğun ve uzun süreli stres uyarımına maruz kalabileceği varsayımı ile bir refah ölçütü olarak kullanılmaktadır (Miller ve ark. 2005).

İnsan-hayvan etkileşimi sonucunda oluşan korku, hayvan refahı ve verimlilik açısından oldukça önemli bir konudur. Çiftlik hayvanlarında korkuya bağlı stres, verimlilik ve ürün kalitesini olumsuz etkileyerek önemli ekonomik kayıplara neden olmaktadır. Yüksek stres ve korku seviyesi, yönetsel uygulamalar esnasında hayvanların daha sik yaralanmalarına sebep olmakta, hayvanlar daha zor idare edilmekte ve sürü yönetimi uygulamalar, için daha fazla zaman harcanmaktadır (Beausoleil 2006).

Gregory (2008), hayvanlarda korku oluşturan durumları; grup bireylerinden ayrı veya yabanc1 ortamlarda tutulma, yabancı ses ve nesnelere maruz kalma, saldırı veya tehditle karşılaşma, yırtıcılar veya yırtıcılara ait ipuçlarına maruz kalma ve daha önceki olumsuz deneyimler ile tekrar karşılaşma şeklinde sıralamaktadır. Gebregeziabhear ve Ameha (2015), ise evcil çiftlik hayvanlarının rutin olarak farklı stres etmenleri ile karşılaştıklarını belirterek, hayvanlar için en stresli koşulları; soğuk, sıcaklık, sürü yönetimi, taşıma, yeni sürüye dâhil olma, hastalık ve parazit olarak sıralamışlardır. (Bickell ve ark. 2009a) ise, koyunların günlük yaşamda düzenli şekilde, bireysel olarak fiziksel ve fizyolojik stres oluşturan, insan, yeni çevre ve yeni uygulamalara maruz kaldığını belirtmektedirler.

\section{Korku davranışlarının değerlendirilmesinde kullanılan yöntemler}

Koyunlarda, korkunun varlığı veya yokluğu açısından yorumlanan davranışları ölçmede kullanılan, korku uyandıran birtakım testler geliştirilmiştir. Bu testler, izolasyon, şaşırtma etkisi, yenilik ve insan varlığı gibi korkuya sebep olduğu bildirilen uyarıcıların varlığına dayandırılmışıtır. Fakat bu gibi uyarıcıların herhangi bir tanesi mükemmel bir standart uyarıcı olarak kabul edilememektedir (Bouissou ve Vandenheede 1995).

Korku hayvanlarda genellikle iki yolla ölçülmektedir. Yöntemlerden ilki; sıfatların her birinin bireysel olarak her hayvanı ne kadar tanımladığı, bir gözlemci tarafından sayısal ölçek kullanılarak sübjektif derecelendirmesi prensibine dayanmaktadır. Yöntemin en büyük dezavantajı gözlemcilerin her hayvan hakkında uzun süreli ve detaylı deneyime sahip olması gerektiğidir. Söz konusu sorun, korku ölçümünün ikinci yöntemi olan, yeni veya şaşırtıcı uyaranın bireye sunulduğu bir veya birden fazla davranışsal tepkinin ölçümünü içeren davranış testleri ile giderilmeye çalışılmışıı. Bu teknik ani ya da yabancı uyarana karşı bireylerin tepkilerinin ölçümü prensibine dayanır. Standart bir yöntemi olmayan bu testlerin prosedürleri büyük ölçüde değişiklik göstermektedir. Bu testler görece daha kısa sürmekte ve hayvanlara aşina olmayan bir gözlemci tarafından objektif ve etkili şekilde yapıllabilmektedir (Miller ve ark. 2005, 2006). 


\section{C. ÇAKMAKÇI, S. KARACA}

Arena Testi:

Arena testi koyunlarda ilk kez cerrahi uygulama stresi sonrası insanlara karşı oluşan hoşnutsuzluğu ölçmek amacıyla geliştirilmiştir (Kilgour 1998). Daha sonra birçok araştırmacı (Murphy ve ark. 1994; Beausoleil ve ark. 2005; Beausoleil ve ark. 2008; Wolf ve ark. 2008; Ligout ve ark. 2011; Beausoleil ve ark. 2012) tarafından koyunlarda kullanılmıştır. Arena testinde, teste tabi tutulan bireyler ile grup üyeleri arasına arena içerisine uyarıcı unsur sunularak koyunlarda yaklaşma/kaçınma motivasyonel çatışması yaratmak amacıyla kullanılmaktadır (Şekil 1). Test süreleri, genel olarak 3-15 dakika arasında değişim gösterir (Forkman ve ark. 2007; Beausoleil ve ark. 2008; Wolf ve ark. 2008; Beausoleil ve ark. 2012). Teste tabi tutulan koyun aynı anda hem grupta bulunan hayvanlara yakın hem de uyarandan uzak olamayacağından dolayı zit motivasyonları arasındaki tercihlerini yansıtan insan ile grup koyunları arasındaki bir mesafede durmak zorundadır. Arena testinde alanlar arasındaki geçiş sayısı hayvanın hareket etkinliğinin bir göstergesi olarak kabul edilmektedir. Arena testinde yüksek veya düşük hareket ve ses etkinliği seviyesi sırasıyla; korkunun yüksek ve düşük seviyesi olarak dikkate alınmaktadır (Blache ve Bickell 2011). Arena testinde ölçülen bazı davranışlar ile korku arasındaki ilişsiler Çizelge 1'de verilmiştir.

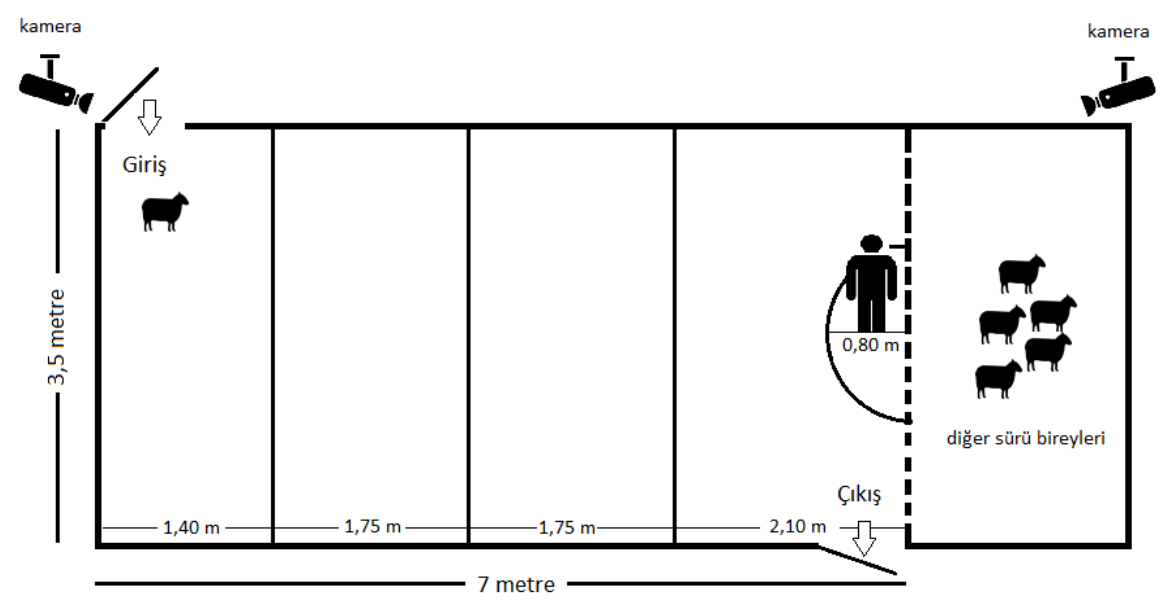

Şekil 1. Arena testi

Çizelge 1. Korku ile ilişkili davranışsal parametreleri (Bouissou ve Vandenheede 1995; Beausoleil ve ark. 2005)'den uyarlanmıştır

\begin{tabular}{lc}
\hline Davranış parametreleri & Korku ile ilişkisi \\
\hline Grup bireylerine ortalama mesafe & + \\
Uyaranı koklamada gecikme süresi & + \\
Uyarana bakma sayısı & + \\
Bölgeler arası geçiş sayısı & + \\
Hareketlilik süresi & + \\
Kaçma girişimi sayısı & + \\
Dişkılama sayısı & + \\
Ses çıkarma sayısı & + \\
Zemini koklama & - \\
Uyaranı koklama sayısı & - \\
Ses çıkarmada gecikme süresi & - \\
\hline
\end{tabular}

+ davranış parametresi korku ile pozitif ilişkili

- davranış parametresi korku ile negatif ilişkili

Bu testte; bireyin grubundan izole edilmesi suretiyle gerçekleştirilir. Potansiyel korkutucu bir nesne veya insan, hayvan ile grubu arasına yerleştirilir. Hayvan güvensizliğini ya da tehdit korkusunu aşmak zorunda bırakılmakta ve hayvanın grubuna katılması için geçen süre ise korku ya da tehdittin ölçüsü olarak alınmaktadır. Bu yeni bir nesnenin yarattığ 1 korkuyu değerlendirmek ya da tanıdık durum ise öğrenilmiş kaçınmayı test etmek için de kullanılabilmektedir (Gregory ve Grandin 1998). Arenada değişik özelliklere ilişkin kalıtım ve tekrarlanma dereceleri Çizelge 2'de verilmiştir. 
Çizelge 2. Arena testinde çeșitli özelliklerin kalıtım ve tekrarlanma dereceleri

\begin{tabular}{lccc}
\hline Davranışlar & Tekrarlanma derecesi & Kalıtım Derecesi & Literatür \\
\hline Ses çıarmada gecikme & $0.58-0.64$ & 0.13 & \\
Ses çikarma sayısı & $0.67-0.71$ & 0.39 & (Wolf ve ark. 2008) \\
Geçilen kare sayıs1 & $0.38-0.40$ & 0.29 & \\
Uyarana olan mesafe & $0.44-0.60$ & 0.22 & \\
\hline
\end{tabular}

Açık-alan Testi:

Açık alan testi ilk olarak 1930'lu yıllarda Calvin S. Hall tarafindan bilimsel araştırmalarda kemirgenlerde genel hareket etkinliği ve endişe düzeyini belirlemek amacıyla kullanılmıştır (Gregory ve Grandin 1998).

Çiftlik hayvanlarında ise türe bağlı olarak farklı ölçülerde etrafı tamamen kapalı bir alanın zemininin karelere bölünmesi suretiyle hayvanın bireysel olarak alan içine alınması (Şekil 2) prensibine dayanmaktadır (Bickell ve ark. 2009a).
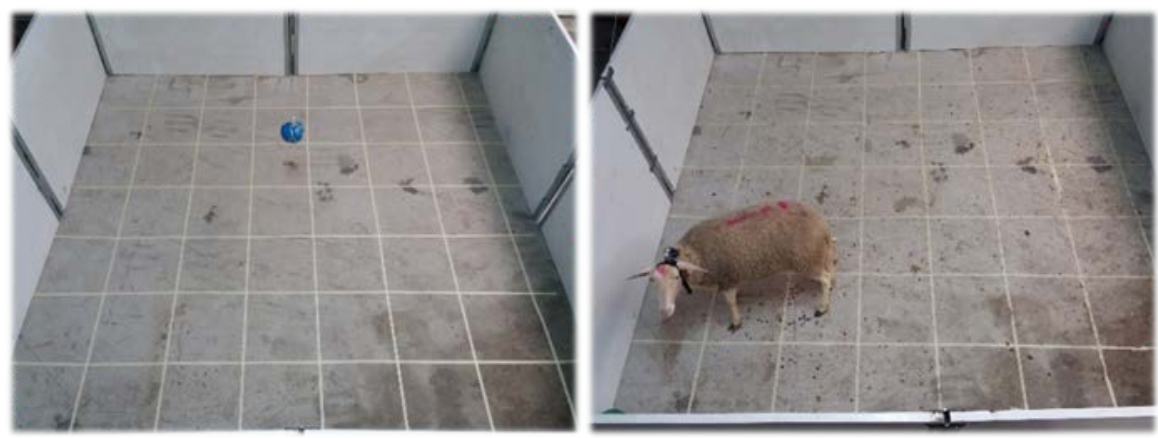

Şekil 2. Açık alan testi

$\mathrm{Bu}$ testte kullanılan alan hayvan türüne ve çalışmalara bağlı olarak farklılıklar göstermektedir. Hayvanlar bireysel olarak test alanına alınarak yaklaşık $5 \mathrm{dk}$ süre boyunca sergiledikleri zemini koklama, hareketlilik, dışkılama, idrar yapma, ses çıkarma ve hareketsizlik gibi davranışlar kaydedilmektedir (Abecia ve ark. 2014).

Kaçış hızı testi:

Kaçış hızı (KH) bir hayvanın tartı kafesinden çıkarken 1.5-1.7 m'lik mesafeyi kaç saniyede aldığının ölçülmesi prensibine dayanmaktadır (Şekil 3). KH ölçümü tartı kafesinin çıkış tarafına bitişik 1.5 veya 1.7 m ara ile iki lazerin konumlandırılmasıyla ölçülmektedir (Dodd ve ark. 2014; Brown ve ark. 2016). Mesafeyi daha kısa sürede alan hayvanın daha fazla korktuğunu ve daha zayıf mizaçlı olduğu kabul edilmektedir (Blache ve Ferguson 2005; Plush ve ark. 2011; Dodd ve ark. 2014). Bu test, yaygin olarak sığırlarda (Hoppe ve ark. 2010) kullanılmaktadır. Koyun ve sığırda kaçış hızı testine ilişkin kalıtım ve tekrarlanma dereceleri Çizelge 3 'de verilmiştir.

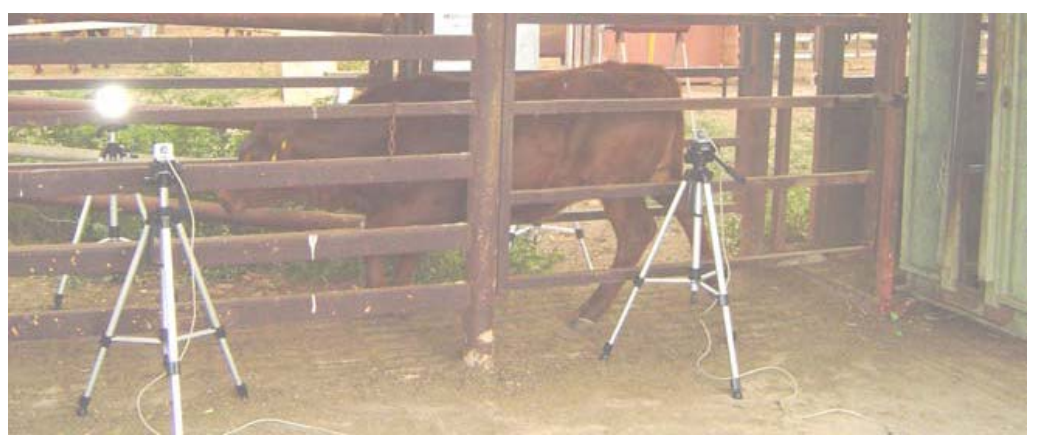

Şekil 3. Sığırlarda kaçış hızı (Anonim 2015) 
Çizelge 3. Koyun ve sığırda kaçış hızı testine ilişsin kalıtım ve tekrarlanma dereceleri

\begin{tabular}{lcl}
\hline Tür & Kalıtım Derecesi $\mathbf{~}^{\mathbf{2}} \mathbf{)}$ & Kaynak \\
\hline Koyun & 0.21 & (Blache ve Ferguson 2005) \\
Koyun & 0.12 & (Plush ve ark. 2011) \\
Koyun & 0.11 & (Dodd ve ark. 2014) \\
Sığır & $0.11-0.36$ & (Hoppe ve ark. 2010) \\
\hline
\end{tabular}

İzolasyon kutusu testi:

Çiftlik hayvanlarının temel özelliklerinden biri olan sürü halinde yaşamalarından dolayı, korku, çeşitli sosyal uyaranlar vasıtasıyla başlatılabilir. Dolayısıyla, sosyal izolasyon, genellikle korkuyu ölçmek için bireysel olarak test edilen tüm sosyal türler için en önemli stres bileşenlerinden biridir (Forkman ve ark. 2007).

Yaygın kabul görmüş ve belirli bir güvenilirlik derecesine sahip koyunlar için geliştirilen testler zaman alıcı (1-15 dk.) ve kullanılan karmaşık test tasarımından dolayı binlerce hayvanla uğraşan çiftlik koşullarına uyarlanamamıştır. Bu zorlukları gidermek amacıyla, koyunlarda mizacı belirlemek için $30 \mathrm{sn}$ izolasyon geliştirilmiştir. Mizaç ve verim özellikleri arasındaki ilişkilerin belirlenmesinde de kullanılmıştır (Blache ve Bickell 2010).

İzolasyon testinde; koyunlar tartım öncesi tamamen kapalı ( $1.5 \mathrm{~m}$ x $0.75 \mathrm{~m}$ x $1.5 \mathrm{~m})$ veya $(1.5 \mathrm{~m}$ x $1.5 \mathrm{~m}$ x $1.5 \mathrm{~m}$ ) boyutlarında bir kutu içerisinde 30 saniye ile 1 dakika süresince tutulmaktadır (Şekil 4). Koyunun ses ve hareketlerine iliş̧in titreşim sayısı, özel amaçlı titreșim ölçer cihazı kullanılarak ölçülmektedir (Murphy ve ark. 1994; Blache ve Ferguson 2005; Blache ve Bickell 2011; Plush ve ark. 2011; Beausoleil ve ark. 2012; Dodd ve ark. 2014; Zambra ve ark. 2015; Brown ve ark. 2016). Uyarılma, doğuştan gelen korkuyu yansıttığı gibi, aynı zamanda hayvanın izolasyona uyum kapasitesini de yansıtmaktadır. Sosyal izolasyona yönelik koyunların davranıșsal tepkilerindeki farklılıkların korku eğilimlerindeki bireysel farklılıkları yansıttı̆̆ı düşünülmektedir (Blache ve Bickell 2011). Koyunlarda izolasyon kutusu puanına ilişkin tekrarlanma ve kalıtım dereceleri Çizelge 4'de verilmiştir.

Çizelge 4. Koyunlarda izolasyon kutusu puanına ilişkin tekrarlanma ve kalıtım dereceleri

\begin{tabular}{ccl}
\hline Tekrarlanma derecesi $(\mathrm{r})$ & Kalitım Derecesi $\left(\mathrm{h}^{2}\right)$ & Literatür \\
\hline 0.59 & 0.35 & (Blache ve Ferguson 2005) \\
- & 0.19 & (Dodd ve ark. 2014) \\
$0.73-0.77$ & - & (Murphy ve ark. 1994) \\
- & 0.2 & (Plush ve ark. 2011) \\
- & $0.18-0.31$ & (Zambra ve ark. 2015) \\
\hline
\end{tabular}

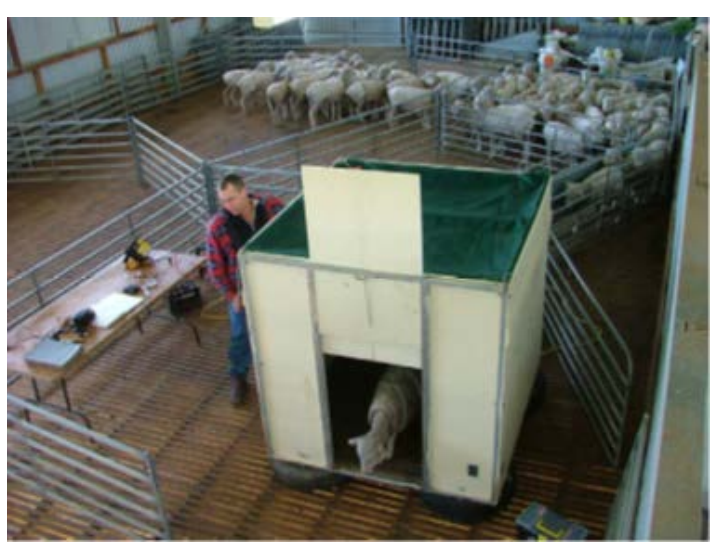

Şekil 4. İzolasyon kutusu (Blache 2007). 


\section{Mizacın hayvan yetiştirmedeki yeri ve önemi}

Evcil hayvan türlerinde, uysallığın evcilleştirme sürecine yardımcı olduğu düşünülmektedir. Yüksek derecede ürkek ve tedbirli bireylerin doğal ortamda daha avantajlı olabileceği yaban hayatta av olma ihtimalinin düşük olacağı öne sürülmektedir. Bunun aksine, evcil koyunlarda sakin mizaçlı olmak, bireylerin eşeysel davranış ve analık kabiliyetini çekinik bireylere göre daha iyi sergilediklerinden, üreme performansını artıran bir özellik olarak görülmektedir (Bickell ve ark. 2009b).

Korku yaratan olayların sıklığının azaltılması veya hayvanlara olumlu deneyimler sağlayan yönetsel uygulamalar, hayvancılıkta yetiştirme koşullarını daha uygun hale getirmede faydalı olabilmektedir. $\mathrm{Bu}$ nedenle, çekinikliği azaltmayı amaçlayan çevresel stratejiler ve seleksiyon hayvansal üretim için ekonomik ve etik (hayvan refahının iyileştirilmesi) açıdan önemli olabilmektedir (Forkman ve ark. 2007). Bickell ve ark. (2009a), sınırlandırılmış çevresel koşullar ile başa çıkmada daha güçlü koyunların seçimi, mizaca yönelik seleksiyon yoluyla sağlanabileceğini belirtmişlerdir.

Beausoleil ve ark. (2012) yönetim uygulamalarını değiştirmenin alternatifi olarak hayvanların özellikle kendilerini değiştirmek olduğunu belirtmektedirler. Dolayısıyla hayvanların endüstriyel üretimle daha iyi başa çıkmaları için özelliklerin belirlenmesi ve seçimine yönelik çalışmalar, evcil hayvanların refahını artırmak için bir yol gösterici olduğunu ifade etmektedirler.

Zorluklara karşı davranışsal tepkilerdeki farklılıkların, koyunlarda mizaca bağlı bireysel farklılıkları yansıttığı düşünülmektedir. Örneğin, sosyal izolasyona gösterilen davranışsal tepkilerdeki farklılığın, korku ile oluşan reaksiyonda koyunların eğilimin hayvandan kaynaklandığı sanılmaktadır (Beausoleil ve ark. 2008).

\section{Mizacın verim özellikleri ile ilişkisi}

\section{Analık davranışı ve kuzu verimi}

Koyunlarda mizaç, analık kabiliyeti ve bunların sürü üretkenliği ile ilişkisini ortaya koyan çalışmaları iki kategoride incelemek mümkündür. Bunlardan biri mizaca göre seleksiyon yapılan sürülerde (popülasyonlarda) mizaç özelliğine ilişkin analık davranışlarını ve bunun sonucunda sürü üretkenliğini inceleyen çalışmalardır. Diğeri ise yavru büyütme yönü ile seleksiyona tabi tutulmuş popülasyonlarda analık davranışlarını ve bunun sonucunda sürü üretkenliğini inceleyen çalışmalardır.

Analık özelliği ile ilişkili davranışlardan doğum öncesi ananın kendini sürüden izole etmesi ana ve yavru arasındaki bağın oluşumundaki ilk adımdır. Bu durum doğum sonrasında ananın yavruyu yalayıp temizliğini kolaylaştırmak ve ses çıkarma eşliğinde memeyi bulup emmesine yardımcı olması ile pekiştirilir (Brown ve ark. 2016). Doğum sonrası kuzu davranışı ve ana davranışı ile kombinasyonu yavrunun hayatta kalma şansını etkilemektedir. Doğum sonrası ananın doğum alanından erken ayrılması, yavruyla arasındaki bağın azalmasına ya da olumsuz olarak etkilemesine neden olabilmektedir. Genel olarak diş faktörlerin etkenleri daha kolay etkilenen tedirgin koyunlarda sakin olanlara kıyasla daha zararlı olabilmektedir (Nowak ve Poindron 2006).

Kuzu ölümleri hem hayvan refahı hem de ekonomik açıdan koyun yetiştiriciliğinde önemli etkilere sahiptir. Kuzuların yaşama gücünü artırıcı stratejiler, doğuracak koyunların beslenmesi, üremenin denetimi ve analık kabiliyetine yönelik koyunların seçimini içermektedir. Ana tarafindan kuzuya gösterilen bakımın niteliği sürüden izolasyon ve doğum stresi ile başa çıkma kabiliyeti de dahil olmak üzere birçok faktörden etkilenmektedir (Blache ve Ferguson 2005).

Mizaca göre seleksiyona tabi tutularak oluşturulmuş popülasyonlarda, örneğin, sakin mizaçlı koyunların analık kabiliyetini daha iyi sergiledikleri (doğum yapılan yerde daha fazla zaman geçirme, doğum sonrası kuzusunu hemen yalayarak kurulama ve kuzusu ile daha fazla meleşme) bildirilmektedir. Bu grup koyunlarda kuzu ölümlerinin tedirgin mizaçlı popülasyonlara göre daha az olduğu bildirilmektedir (Murphy ve ark. 1994). Ancak yakın zamanlarda yapılan çalışmalarda, mizaç yönü ile seleksiyona tabi tutulmuş popülasyonlarda kuzu yaşama gücü yönü ile farklılıkların olmadığı ortaya konulmuştur (Bickell ve ark. 2009a). Ayrıca, öngörülenin aksine, mizaç yönü ile seleksiyona tabi tutulmamış koyunlarda yapılan bir çalışmada, tedirgin mizaç ile kuzu yaşama gücü arasında pozitif korelasyon olduğu 


\section{C. ÇAKMAKÇI, S. KARACA}

belirlenmiştir (Plush ve ark. 2011). Bu bulgular mizaç ile analık kabiliyeti arasındaki ilişkinin henüz tam olarak açıklanmamış olduğunu göstermektedir.

Kuzu büyütme özelliği bakımından seleksiyona tabi tutulmuş popülasyonlarda, çoklu kuzu büyütme yönü ile geliştirilen sürülerde analık kabiliyetinin daha iyi olduğu belirlenmiştir. $\mathrm{Bu}$ sürülerde kuzularda yaşama gücünün daha yüksek olduğu bildirilmektedir. Mizaç özellikleri yönüyle de değerlendirildiklerinde bu sürülerin sakin mizaç özelliklerine sahip oldukları görülmektedir (Hough ve ark. 2013). Mevcut bulgular, çoklu yavru yetiştirebilme özelliği dikkate alınarak yapılan seleksiyonla kuzu yaşama gücünde genetik ilerleme kaydedilebileceğini, bunun sonucu olarak da popülasyonlarda üretkenliğin sağlanabileceğini göstermektedir.

Ekstansif koşullarda yetiştirilen koyunların sıklıkla alışık olmadıkları durumlarla karşılaşmakta ve bu koşullarda tedirgin koyunların yavruları sakin olanlara kıyasla gebelik döneminde glukokortikoidlere yüksek düzeyde maruz kalabilmektedir. $\mathrm{Bu}$ durum tedirgin koyun yavrularının stresle başa çıkma kabiliyetlerini zayıflatarak strese daha hassas olmalarına sebep olabilmektedir (Bickell ve ark. 2009a). Doğum sonrası analık davranışlarına karşı genotipin göreli katkıları çapraz yakma yöntemini kullanarak yetiştirilen Merinos kuzularında, davranışların anneden öğrenilmiş davranışlardan ziyade, özelliğin generasyonlar arası genetik aktarımı ile belirlenmekte olduğu ifade edilmektedir (Bickell ve ark. 2009a). Gavojdian ve ark. (2015) Dorper koyunlarında mizacın kalıtım derecesinin $0.10 \pm 0.03$ olarak hesaplamış ve mizaç ile sütten kesim öncesi ve sütten kesimden sonraki 120. gün büyüme oranı arasında önemli oranda genetik korelasyon tespit etmişlerdir. Pajor ve ark. (2010) ise sakin koyunların kuzuları sütten kesim öncesi ve sonrasında canlı ağırlık artışları bakımından ürkek olanlara kıyasla daha yüksek ve besi performanslarının da daha iyi olduğunu bildirmişlerdir. (Kilgour 1998) kuzu büyütme kabiliyetinin iyileştirilmesinde olası bir seleksiyon kriteri olarak arena davranışları yararlı olabileceğini bildirmekte ve bu davranışların her iki cinsiyette de yaşamlarının erken döneminde ölçülebilmesi halinde hızlı bir genetik ilerlemenin sağlanabilmesinin mümkün olabileceğini ifade edilmektedir.

\section{Süt verimi ve bileşimi}

Süt verimini artırma olasılığı yüksek olan koyunların damızlık olarak seçimi için uygun seleksiyon yöntem ya da özelliklerini belirlemek, sürdürülebilir koyun sütü endüstrisinin gelişimi açıcından önemlidir (Murray ve ark. 2006). Ürkek hayvanlar, sakin olanlara kıyasla daha stres faktörlerine daha hızlı yanıt vermekte ve süt verimleri olumsuz etkilenebilmektedir (Stoycheva ve ark. 2015). Stres, sağım sırasında hayvanlarda süt verimini azaltır (Murray ve ark. 2006) ve sütün indirilmesi refleksini inhibe eden katekolamin salınımını artırarak sütün bileşimini etkileyebilmektedir (Murray ve ark. 2006; Stoycheva ve ark. 2015).

Mizaç ile süt özellikleri arasındaki ilişkileri inceleyen birbirinden farklı sonuçlar elde etmiş çalışmalar mevcuttur. Örneğin, mizacın sütün miktar ve bileşimi (protein, ya ve kuru madde vb) koyun (Murray ve ark. 2006), keçi (Stoycheva ve ark. 2015) ve sığır türünde (Orbán ve ark. 2011) süt verimini etkilemediği bildirilmiştir. Buna karşın, sakin mizaçlı koyunların ürkek koyunlara oranla daha fazla süt ürettikleri, mizacın kortizol ve laktik asit düzeyi ile yüksek derecede bir ilişki içerisinde olduğu ifade edilmektedir. Bununla birlikte ürkek koyunların kortizol ve laktik asit düzeylerinin daha yüksek olduğu bildirilmektedir (Pajor ve ark. 2010). Benzer şekilde, Jersey ve Siyah Alaca ineklerde Somatik hücre sayısı ile mizaç arasında pozitif bir ilişki olup çok yüksek olmayan bir korelayon söz konusudur ve sakin mizaçlı ineklerin daha düşük SHS sahip olduklarını ifade edilmektedir (Orbán ve ark. 2011).

\section{Besi performansl, karkas ve et kalitesi}

Mizacın koyunlarda karkas ve et kalitesi ile ilişkisini inceleyen çalışmalar (Pajor ve ark. 2008; Dodd ve ark. 2014) sınırlıdır. Ancak sığırlarda birbirinden farklı sonuçlar bildiren çalışmalar (Behrends ve ark. 2009; Silveira ve ark. 2012; Magolski ve ark. 2013; Coombes ve ark. 2014) mevcuttur. Koyunlarda mizaçlarına göre iki gruba ayrılarak besi performanslarının değerlendirildiği çalışmada sakin mizaçlı koyunların besi sonu canlı ağırlıkları ve günlük canlı ağırlık artışlarının önemli düzeyde yüksek olduğu bildirilmiştir (Pajor ve ark. 2008). Ancak, kuzularda yapılan bir çalışmada, sütten kesimde ölçülen mizaç ile kesim karkas özellikleri arasındaki fenotipik ve çevresel korelasyonlar çok düşük veya önemsiz bulunmuştur. Ayrıca genetik korelasyonların da çoğunlukla önemsiz veya zayıf olması, kuzuların mizacına yönelik seleksiyonun karkas kalitesi üzerine çok az veya hiç etkisinin olmayacağı ifade 
edilmiştir (Dodd ve ark. 2014). Buna karşın, besi sığırlarında yapılan çalışmada ise sütten kesimde ölçülen mizacın günlük canlı ağırlık artışı, göz kası alanı, ürün derecesi (kemiksiz perakende satılabilir ürünlerin miktarı) ve kesme direnci ile ilişkisinin besi dönemi sonunda yapılan mizaç ölçümü ile olan ilişkisinden daha yüksek olduğu bildirilmiştir (Behrends ve ark. 2009). Dolayısıyla sütten kesimde ölçülen mizacın ekonomik öneme sahip özelliklerle ilişkisinin daha yüksek olması, hayvanların sürü yönetim uygulamalarına alı̧̧adan, erken dönemde değerlendirilmesi mizacın doğuştan gelen varyasyonun daha hassas bir ölçütü olabileceği şeklinde ifade edilmiştir (Behrends ve ark. 2009). Ancak, mizaç ile post-mortem protein parçalanması ve kalpain enzim aktivitesi arasında bir fenotipik korelasyon olmaması, alternatif bir mekanizmanın bu ilişkiden sorumlu olabileceği ifade edilmektedir (Magolski ve ark. 2013).

Benzer şekilde, sı̆̆ırlarda yapılan başka bir çalışmada ise, mizaç sınıflarının genel et kalite özelliklerini etkilemediğini (Silveira ve ark. 2012) ancak, ürkek sığırların günlük canlı ağırlık artışı, kuru madde tüketimlerinin düşük ve yem değerlendirmelerinin daha kötü olduğu ifade edilmektedir (Silveira ve ark. 2012). Farklı yaş ve cinsiyetteki sığırlarda mizacın kas glikojen konsantrasyonu ve nihai pH'yı etkilemediği bildirilmekte ancak, mizaç skorlarındaki artışa bağlı olarak kas ve plazma laktat konsantrasyonlarında oransal olarak artış gözlendiği ve dolayısıyla kesim hemen öncesi süreçte ürkek hayvanların daha fazla glikojen mobilize ettikleri ifade edilmektedir (Coombes ve ark. 2014).

\section{Üreme performansl}

Mizacın üreme performansı üzerindeki etkisi, oldukça karmaşık bir fenomendir. Özellikle post-partum erken dönemde stres kaynaklarının etkileri konusunda net bir cevap yoktur (Blache ve Bickell 2010). Üreme performansına ilişkin kuzularda yaşama gücü, mizaca bağlı sadece ana-yavru bağının oluşumu ile ilgili değil, ayrıca mizaca göre seleksiyon ile enerji paylaşımı koyunlarda üremenin farklı aşamalarını etkileyebilmektedir (Blache ve Bickell 2011). Üreme endokrin aksı stresten önemli derecede etkilenmekte ve koyunların mizaca göre seleksiyona gösterdikleri yanıt farklı olabilmekte/ farklılık gösterebilmektedir (Blache ve Bickell 2011). Örneğin mizaçlarına göre sınıflandırılmış sakin ve ürkek koyunların deneyimsiz (1-2 yaş) ve deneyimli (3-4 yaş) olmak üzere iki farklı yaş kategorisinde 14 günlük intravaginal sünger uygulamasının bitiminden sonraki ilk 32,48 ve 72 saatlerde sakin koyunların daha fazla eşeysel davranış sergilediğini ve benzer şekilde deneyimli koyunlarında her iki mizaç grubunda genç olanlara kıyasla sünger uygulama sonrası 64 saatte daha fazla eşeysel davranış sergilediği ifade edilmektedir. Dolayısıyla mizaç ve deneyimin koyunlarda sürü yönetimi uygulamalarında dikkate alınması gereken iki faktör olduğu ifade edilmektedir (Gelez ve ark. 2003). Aynı koşullarda mizaçlarına göre sakin ve ürkek olarak iki farklı soy olarak yetiştirilen koyunlardan sakin olanlarda ovulasyon oranı ürkek olanlara kıyasla daha yüksek, ancak gebelik oranları benzer bulunmuştur (van Lier ve ark. 2017). Benzer şekilde, Reale ve ark. (2000) iri boynuzlu yaban koyunlarında sakin olanların ürkeklere göre eşeysel olgunluğa daha erken ulaştıkları ve sütten kesimde daha başarılı olduklarını ifade emektedirler. Buna karşın, Chanvallon ve ark. (2010) eşeysel deneyimi olmayan koyunlarda koç etkisinin sakin koyunlara kıyasla ürkek koyunlarda cinsel aktiviteyi arttırdığını bildirmişlerdir.

\section{Sonuç}

Son yıllarda gerek hayvan refahının iyileştirilmesi gerekse üretimin arttırılmasına yönelik çabaların hız kazanmış olması bu alana yönelik yeni yaklaşımlara ihtiyaç duyulduğunu göstermektedir. Mizaç, hayvan 1slahı programlarında önemli yer teşkil etmeye başlamışıtır. Mizaç ile verim özellikleri arasındaki ilişkileri hedef alan çalışmalar uysallığın sslah programlarında yararlanılabilir seviyede eklemeli genetik varyans ortaya koyduğunu bildirmektedir. Mizacın kalıtsal bir bileşeninin var olması; daha az korku gösteren bireylerin damızlığa seçimi, hayvansal üretimde istenen yapıda sürüleri elde etmek, hayvan refahını korumak ve verimliliği iyileştirmeye yönelik bir yöntem olarak görülmektedir.

Uysallığın ölçümünde kullanılan teknikler, uysallığın daha doğru olarak belirlenebilmesi için sürekli olarak değiştirilip geliştirilmektedir. Koyunlarda mizacın belirlenmesine yönelik Türkiye'deki çalışmalar oldukça sınırlıdır. Dolayısıyla; yerli koyun ırklarının bu açıdan tanımlanmasının ıslah programlarına katkı sağlayabileceğini söylemek mümkündür. 


\section{Kaynaklar}

Abecia JA, Casao A, Pascual-Alonso M, Lobon S, Aguayo-Ulloa LA, Meikle A, Forcada F, Sosa C, Marin RH, Silva MA, Maria GA (2014). The effect of periconceptional undernutrition of sheep on the cognitive/emotional response and oocyte quality of offspring at 30 days of age. J Dev Orig Health Dis 5: 79-87.

Anonim (2015). http://breedplan.une.edu.au/tips/Recording\%20Flight\%20Time.pdf. (Erişim:08.12.2015).

Beausoleil NJ (2006). Behavioural and physiological responses of domestic sheep (Ovis aries) to the presence of humans and dogs, Massey University, Palmerston North, New Zealand.

Beausoleil NJ, Blache D, Stafford KJ, Mellor DJ, Noble ADL (2008). Exploring the basis of divergent selection for 'temperament' in domestic sheep. Applied Animal Behaviour Science 109: 261-274.

Beausoleil NJ, Blache D, Stafford KJ, Mellor DJ, Noble ADL (2012). Selection for temperament in sheep: Domain-general and context-specific traits. Appl Anim Behav Sci 139: 74-85.

Beausoleil NJ, Stafford KJ, Mellor DJ (2005). Sheep show more aversion to a dog than to a human in an arena test. Applied Animal Behaviour Science 91: 219-232.

Behrends SM, Miller RK, Rouquette Jr FM, Randel RD, Warrington BG, Forbes TD, Welsh TH, Lippke H, Behrends JM, Carstens GE, Holloway JW (2009). Relationship of temperament, growth, carcass characteristics and tenderness in beef steers. Meat Science 81: 433-438.

Bickell S, Poindron P, Nowak R, Chadwick A, Ferguson D, Blache D (2009a). Genotype rather than nongenetic behavioural transmission determines the temperament of Merino lambs. Animal Welfare 18: 459-466.

Bickell SL, Nowak R, Poindron P, Sebe F, Chadwick A, Ferguson D, Blache D (2009b). Temperament does not affect the overall establishment of mutual preference between the mother and her young in sheep measured in a choice test. Dev Psychobiol 51: 429-438.

Blache D (2007). Temperament and animal welfare Industry forums: Innovations in animal production to meet consumer expectations, The UWA Institute of Agriculture. http://www.ioa.uwa.edu.au/_data/assets/pdf_file/0004/1147468/Welfare-and-Temperament.pdf.

Blache D, Bickell SL (2010). Temperament and reproductive biology: emotional reactivity and reproduction in sheep. Revista Brasileira de Zootecnia 39: 401-408.

Blache D, Bickell SL (2011). External and internal modulators of sheep reproduction. Reprod Biol 11 Suppl 3: 61-77.

Blache D, Ferguson D (2005). Boost lamb survival - select for calm ewes Agribusiness sheep updates. p 9-10, Perth.

Bouissou MF, Vandenheede M (1995). Fear Reactions of Domestic Sheep Confronted with Either a Human or a Human-Like Model. Behavioural Processes 34: 81-92.

Broom DM (2003). Causes of poor welfare in large animals during transport. Vet. Res. Commun 27: 515518.

Broom DM (2008). Welfare Assessment and Relevant Ethical Decisions: Key Concepts. ARBS Annu. Rev. Biomed. Sci. 10: 79-90.

Brown DJ, Fogarty NM, Iker CL, Ferguson DM, Blache D, Gaunt GM (2016). Genetic evaluation of maternal behaviour and temperament in Australian sheep. Animal Production Science 56: 767774.

Chanvallon A, Blache D, Chadwick A, Esmaili T, Hawken PAR, Martin GB, Viñoles C, Fabre-Nys C (2010). Sexual experience and temperament affect the response of Merino ewes to the ram effect during the anoestrous season. Animal Reproduction Science 119: 205-211.

Coombes SV, Gardner GE, Pethick DW, McGilchrist P (2014). The impact of beef cattle temperament assessed using flight speed on muscle glycogen, muscle lactate and plasma lactate concentrations at slaughter. Meat Sci 98: 815-821.

Dawkins MS (2004). Using behaviour to assess animal welfare. Anim Welfare 13: S3-S7.

Dodd CL, Hocking Edwards JE, Hazel SJ, Pitchford WS (2014). Flight speed and agitation in weaned lambs: Genetic and non-genetic effects and relationships with carcass quality. Livestock Science 160: $12-20$.

Dodd CL, Pitchford WS, Edwards JE, Hazela SJ (2012). Measures of behavioural reactivity and their relationships with production traits in sheep: A review. Appl Anim Behav Sci 140: 1-15.

Earley B, Buckham-Sporer K, Gupta S, Pang W, Ting S (2010). Biologic response of animals to husbandry stress with implications for biomedical models. Open Access Anim Physiol: 25.

Etim NN, Evans EI, Offiong EEA, Williams ME (2013). Stress and the neuroendocrine system: implications for animal well-being American Journal of Biology and Life Sciences 1: 20-26. 
Forkman B, Boissy A, Meunier-Salauen MC, Canali E, Jones RB (2007). A critical review of fear tests used on cattle, pigs, sheep, poultry and horses. Physiology \& Behavior 92: 340-374.

Gavojdian D, Cziszter LT, Budai C, Kusza S (2015). Effects of behavioral reactivity on production and reproduction traits in Dorper sheep breed. Journal of Veterinary Behavior-Clinical Applications and Research 10: 365-368.

Gebregeziabhear E, Ameha N (2015). The effect of stress on productivity of animals:A review. Journal of Biology, Agriculture and Healthcare 5: 165-172.

Gelez H, Lindsay DR, Blache D, Martin GB, Fabre-Nys C (2003). Temperament and sexual experience affect female sexual behaviour in sheep. Applied Animal Behaviour Science 84: 81-87.

Gregory NG (2008). Physiology and Behaviour of Animal Suffering. Blackwell Publishing, Iowa.

Gregory NG, Grandin T (1998). Animal Welfare and Meat Science. CABI, UK.

Hoppe S, Brandt HR, Konig S, Erhardt G, Gauly M (2010). Temperament traits of beef calves measured under field conditions and their relationships to performance. J Anim Sci 88: 1982-1989.

Hough D, Swart P, Cloete S (2013). Exploration of the Hypothalamic-Pituitary-Adrenal Axis to Improve Animal Welfare by Means of Genetic Selection: Lessons from the South African Merino. Animals 3: 442.

Kilgour RJ (1998). Arena behaviour is a possible selection criterion for lamb-rearing ability; it can be measured in young rams and ewes. Applied Animal Behaviour Science 57: 81-89.

Ligout S, Foulquie D, Sebe F, Bouix J, Boissy A (2011). Assessment of sociability in farm animals: The use of arena test in lambs. Appl Anim Behav Sci 135: 57-62.

Lupien SJ, Maheu F, Tu M, Fiocco A, Schramek TE (2007). The effects of stress and stress hormones on human cognition: Implications for the field of brain and cognition. Brain Cogn 65: 209-237.

Magolski JD, Berg EP, Hall NL, Anderson VL, Keller WL, Jeske TM, Maddock Carlin KR (2013). Evaluation of feedlot cattle working chute behavior relative to temperament, tenderness, and postmortem proteolysis. Meat Sci 95: 92-97.

Miller KA, Garner JP, Mench JA (2005). The test-retest reliability of four behavioural tests of fearfulness for quail: a critical evaluation. Appl Anim Behav Sci 92: 113-127.

Miller KA, Garner JP, Mench JA (2006). Is fearfulness a trait that can be measured with behavioural tests? A validation of four fear tests for Japanese quail. Anim Behav 71: 1323-1334.

Moberg GP, Mench JA (2000). The Biology of Animal Stress: Basic Principles and Implications for Animal Welfare. CABI Pub.

Murphy PM, Purvis IW, Lindsay D, Le Neindre P, Orgeur P, Poindron P (1994). Measures of temperament are highly repeatable in Merino sheep and some are related to maternal behaviour 20th Biennial Conference of the Australian Society of Animal Production No. 20. p 247-250. Australian Society of Animal Production, Pert.

Murray TL, Blache D, Bencini R (2006). Calm dairy ewes produce more milk than nervous dairy ewes. In: K. Croker, N. Adams ve D. Lindsay (eds.) 26th Biennial Conference Australian Society of Animal Production. p 44. Australian Society of Animal Production:, Perth, Western Australia.

Nowak R, Poindron P (2006). From birth to colostrum: early steps leading to lamb survival Reprod. Nutr. Dev No. 46. p 431-446.

Orbán M, Kovácsné Gaál K, Pajor F, Szentléleki A, Póti P, Tőzsér J, Gulyás L (2011). Effect of temperament of Jersey and Holstein Friesian cows on milk production traits and somatic cell count (Short Communication). Archiv Tierzucht 54: 594-599.

Pajor F, Murányi A, Szentléleki A, Tőzsér J, Póti P, Murányi A, Szentléleki A, Tözsér J, Póti P (2010). Effect of temperament of ewes on their maternal ability and their lambs' postweaning traits in Tsigai breed. Archiv Tierzucht 53: 465-474.

Pajor F, Szentleleki A, Laczo E, Tozser J, Poti P (2008). The effect of temperament on weight gain of Hungarian Merino, German Merino and German Blackhead lambs. Archiv Fur TierzuchtArchives of Animal Breeding 51: 247-254.

Pehlivan E, Dellal G (2014). Memeli çiftlik hayvanlarında stres, fizyoloji ve üretim İlişkileri. Hayvansal Üretim 55: 25-34.

Plush KJ, Hebart ML, Brien FD, Hynd PI (2011). The genetics of temperament in Merino sheep and relationships with lamb survival. Applied Animal Behaviour Science 134: 130-135.

Ralph CR, Tilbrook AJ (2016). The usefulness of measuring glucocorticoids for assessing animal welfare. J Anim Sci 94: 457-470.

Reale D, Gallant BY, Leblanc M, Festa-Bianchet M (2000). Consistency of temperament in bighorn ewes and correlates with behaviour and life history. Anim Behav 60: 589-597. 
Rice VH (2000). Theories of stress and relationship to health. In: V. H. Rice (ed.) Handbook of stress, coping, and health: Implications for nursing research, theory, and practice. p 27-45. Thousand Oaks, Sage.

Selye H (1952). The story of the adaptation syndrome (Told in the form of informal, illustrated lectures). Acta, Inc. - Medical Publishers.

Silveira IDB, Fischer V, Farinatti LHE, Restle J, Filho DCA, de Menezes LFM (2012). Relationship between temperament with performance and meat quality of feedlot steers with predominantly Charolais or Nellore breed. Rev. Bras. Zootec 41 1468-1476.

Stoycheva S, Hristova T, Zunev P (2015). Influence of the Temperament Over The Milk-Yield of Goats of Bulgarian White Milk Breed and Its Cross-Breeds With Togenburg and Anglo-Nubian Breed. Türk Tarım ve Doğa Bilimleri-Turkish Journal of Agricultural and Natural Sciences 1: 20462048.

van Lier E, Hart KW, Viñoles C, Paganoni B, Blache D (2017). Calm Merino ewes have a higher ovulation rate and more multiple pregnancies than nervous ewes. animal: 1-7.

Wolf BT, McBride SD, Lewis RM, Davies MH, Haresign W (2008). Estimates of the genetic parameters and repeatability of behavioural traits of sheep in an arena test. Appl Anim Behav Sci 112: 6880.

Zambra N, Gimeno D, Blache D, van Lier E (2015). Temperament and its heritability in Corriedale and Merino lambs. Animal 9: 373-379 